\title{
MARTA FONCERRADA
}

El 25 de mayo de 1988 murió, en la ciudad de México, Marta Foncerrada de Molina. Desde 1965 era investigadora de este Instituto de Investigaciones Estéticas, casi veinticinco años de una fecunda tarea. Su espíritu colaborador y su desprendida generosidad ayudaron a hacer de Marta Foncerrada de Molina un ser, una persona a la que se extrañará siempre y cuyo recuerdo nunca será traicionado por los años.

Su quehacer académico se repartió entre la docencia y las indagaciones, principalmente de nuestro más antiguo pasado: del arte prehispánico, del universo Maya. Allí están sus obras como exponentes de una auténtica seriedad, de un conocimiento hondo que rebasaba lo libresco para llegar a la convivencia esencial de los trabajos de campo. Su estilo ameno y entendido, directo y responsable la volvió en los últimos años uno de los puntales más considerados de nuestro Instituto.

Por estas razones y otras tantas, este número de Anales correspondiente al año de 1988 se dedica por decisión unánime del Colegio de Investigadores para honrar su memoria. Un modesto homenaje para una gran compañera, para una sabia amiga, para una ejemplar maestra cuya reconocida sensatez será siempre aliento y norma en el Instituto de Investigaciones Estéticas.

Elisa García Barragán DIRECTORA 
DOI: http://dx.doi.org/10.22201/iie.18703062e.1989.60.1539 
DOI: http://dx.doi.org/10.22201/iie.18703062e.1989.60.1539

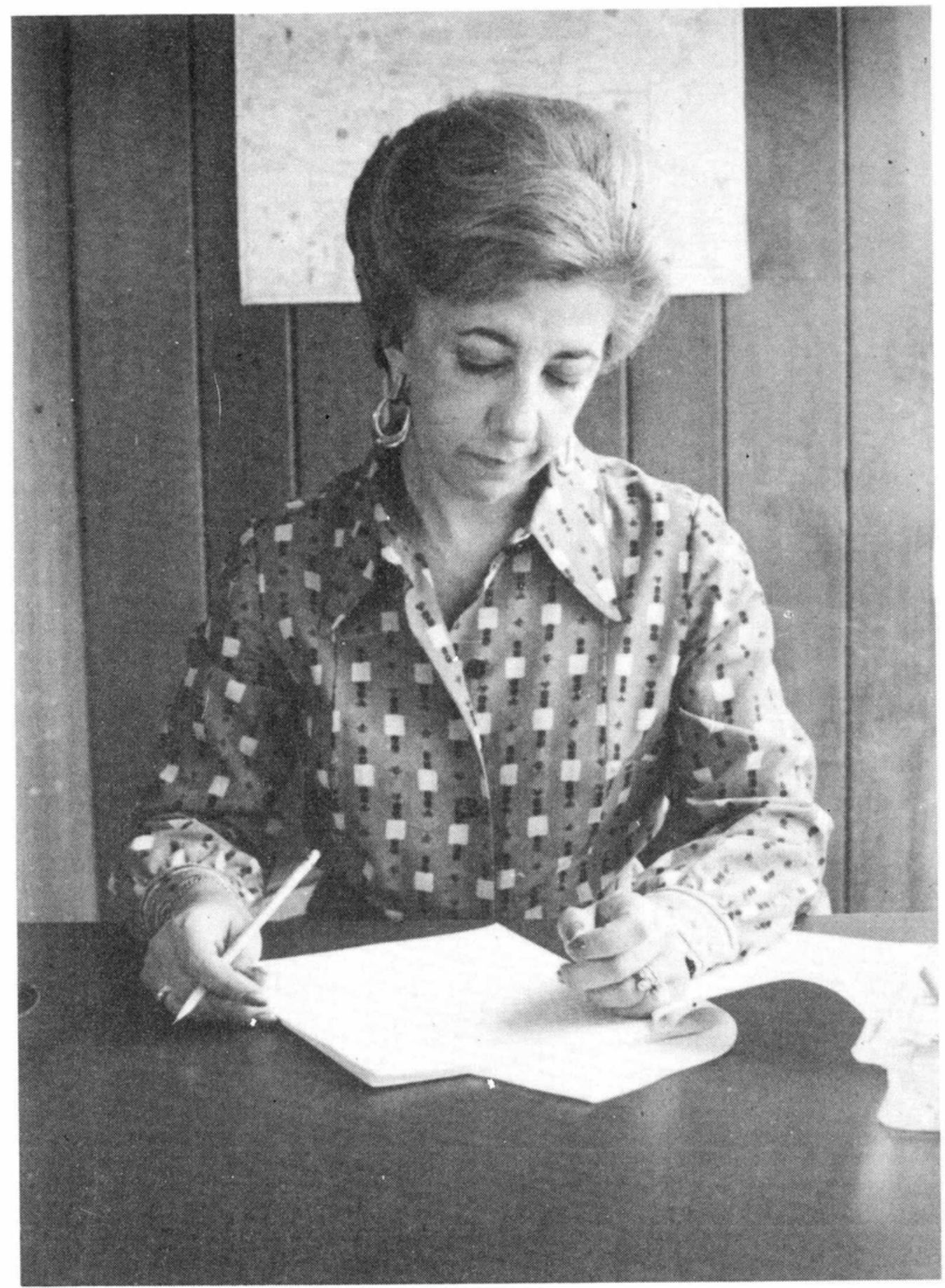

Marta Foncerrada de Molina. 